\title{
2012: A ROUSSEAU-ÉV
}

\section{DócZI-VÁMos GABRIELLA}

\author{
az Eötvös Loránd Tudományegyetem Pedagógiai és Pszichológiai Karának \\ doktorandusz hallgatója \\ gab.vamos@gmail.com
}

Jean-Jacques Rousseau 1712-ben született Genf városában, ahol életének első éveit is leélte, ezért nem csoda, hogy születésének 300. évfordulóját rendezvények sorozatával ünnepelték Svájcban. De így tettek Franciaország-szerte is, valamint Németországban, az Egyesült Államokban, Dániában, sőt még közép- és dél-Amerikában is. Ezekről a 2012-es ünnepi évi eseményekről több weboldal is tájékoztatást ad. Jelen írás ezekre támaszkodva kíván ízelítőt adni.

A rendezvénysorozatot - a Rousseau Egyesület ${ }^{1}$ (Rousseau Association) leírása szerint - Genf városa indította el 2012. január 19-én a genfi Rousseau-szigeten és ugyanezt tette Franciaország január 20-án a Rhône-Alpes régióban, Chambéryben. Ez a két ország egész évben tartó programsorozatot kínált az érdeklődőknek. Az egyik legkomplexebbet, Genf kulturális és sport osztálya szervezte, multidiszciplináris és nemzetközi ünnepségsorozatként Rousseau mindenkinek (2012 Rousseau for All / 2012 Rousseau pour tous) címen. Ennek keretében zenei, színházi és filmmủvészeti rendezvények, kiállítások és konferenciák szórakoztatták a látogatókat. A legnagyobb érdeklődés minden bizonnyal a „,JJR (A genfi polgár)"” [,,JJR (Citizen of Geneva)"'] nevű opera világpremierjét kísérte, amit a genfi nagyszínházban mutattak be 2012. szeptember 9. és 24. között; a darabot Philippe Fénelon komponálta és Robert Carsen rendezte, a szövegét Ian Burton írta. Az opera világában maradva, e helyszín otthont adott a 2012 januárjában bemutatásra került két operának, Giovanni Battista Pergolesi Az úrhatnám szolgáló (La Serva padrona) címü müvének, és az ennek hatására Jean-Jacques Rousseau által megírt, a korában népszerü, ma már kevéssé ismert és játszott $A$ falusi jós (Le Devin du village) címú egyfelvonásos vígoperának. A másik, a Tic-tac Rousseau pedig, egy marionett bábukra írt opera, ami novemberben került a közönség elé négy alkalommal. Ez a darab könnyed és friss megközelítésből ábrázolja a genfi írót; a hallgatóság szimbólumokon és utcazenén keresztül érezheti meg a korabeli atmoszférát.

\footnotetext{
${ }^{1}$ A Rousseau Egyesület egy multinacionális és interdiszciplináris szervezet, amely tagjai között tudhat szakembereket a történelem, nyelvek, irodalom, filozófia, politológia és egyéb tudományterületekről szerte a világon, így például az Egyesült Államokból, Kanadából, Mexikóból, Európából és Japánból.
} 
Az operától kissé ugyan eltávolodva, de a zenei világban folytatva, Genf otthont adott még a Lux Borea nevü norvég zenekar barokk zenei estjének is. A hallgatóság számára ingyenes zenei különlegesség egy nagyobb turné egyik állomása volt, ezért csak egy alkalommal adták elő a városban. A zenészek ízelítöt adtak abból a zenei világból, ami Rousseau-t is körülvehette, s közben a filozófus zenével kapcsolatos feljegyzéseit olvasták fel.

Négy filmet mutattak be a rousseau-i évben. Az egyik a genfi nyitónapon debütált, január 19-én Rousseau tévedése (La faute à Rousseau) címmel, ami Rousseau írásai által inspirált rövidfilmek sorozata. A négyperces rövidfilmek a legkülönfélébb stílust képviselik, a legváratlanabb fikciótól kezdve az animációig. Egy másik film címe talán egy szójátékra is épít, Az orr a patakban (Le nez dans le ruisseau). A film arról szól, hogy Rousseau eszméi még mindig jelen vannak a kortárs társadalomban. A film levetítése előtt egy pár perces színházi előadás is bemutatásra került, ami Rousseau Genfböl Confignon-ba menekülését mutatta be. Levetítésre került még az Az én új Héloïse-om (Ma Nouvelle Héloïse) címü film, ami a La Nouvelle Héloïse filmadaptációja, valamint egy film Rousseau kevéssé ismert - és talán kimondható, hogy kevésbé elismert - zenész oldaláról.

Svájc egy másik városa, Neuchâtel is egész évben rendezvények sorozatával kínálta meg az érdeklődőket, de nem csak Rousseau születésének 300. évfordulójának megünneplésére épített, hanem Môtiers-ba érkezésének 250. évfordulójára is, hiszen 1762-tól 1765-ig húzta meg magát itt az után, hogy Párizsban elítélték két munkája, a Társadalmi szerzödés és az Émile miatt. Egy weboldalt Rousseau chemins ouverts, 1712-2012 (Rousseau nyilt utak, 1712-2012) is létrehoztak a körülbelül 40 program bemutatására, népszerüsítésére. A programok között a többi helyszínhez hasonlóan találunk előadásokat, konferenciákat, felolvasásokat, zenei programokat, kiállításokat és egy nagyon érdekes programot is, egy vezetett túrát is, ami Rousseau életének különböző helyszínein vezet végig.

Franciaországban a Rhône-Alpes régióban is egész évben programok várták az érdeklődőket, színházi előadások, viták, koncertek, kiállítások. A lyioni Városi Könyvtárban (Bibliothèque municipale de Lyon) tárlatot szerveztek Rousseau Annecyben majd Chambéry-ben, nevezetesen Charmettes-ben töltött 14 évéröl. A kiállítás lehetőséget adott arra, hogy újra megismerjük az embert és az írót, olyan ritkaságok bemutatásával, mint $A$ falusi jós címủ opera kézirata. A könyvtár számos koncertet, előadást, felolvasást, látogatást és botanikai mühelyt szervezett április és július között. Továbbá, Rousseau születésének napján, június 28-án, pikniket szerveznek különbözö városokba, így például Bourg-en-Bresse-be, Miribel-be, Grignan-ba, Goncelin-be, Grenoble-ba, Aix-les-Bains-be, Thuyets-be és Brindas-ba. Ezeken a piknikeken amatőr és profi színészek olvastak fel részleteket Rousseau különbözö műveiből, úgy mint a Vallomások, Émile, vagy az Értekezés az emberek közötti egyenlötlenség eredetéröl és alapjairól-ból. 
A Francia Nemzeti Könyvtár [Bibliothèque nationale de France $(\mathrm{BnF})]$ is tisztelettel adózik a termékeny munkásságú felvilágosult filozófus elött. A február 9-én megrendezésre került „Rousseau és a forradalom” címü szimpóziumot az azonos címü kiállítás, követte, ami február 10. és április 6. között volt látogatható az Országgyülés házában. A kivételes kéziratok gyüjteményét az Országgyülés könyvtára és a Francia Nemzeti Könyvtár állította össze, a tárlatot a Carnavalet Múzeum, a Francia Intézet, a Jean-Jacques Rousseau Múzeum és a Genfi Könyvtár egészítette ki. Az intézmények gyüjteményüket digitalizálták és a nagyközönség olyan különlegességeket nézhetett meg, mint egy egyedülálló kézirat, amit Jean-Jacques Rousseau, az autodidakta utazó írt és látott el jegyzetekkel.

Rousseau születésének 300. évfordulója a világ számos más városában is megmozdította a rajongókat. Párizsban több nemzetközi szimpóziumot is szerveztek: ,,Rousseau és a forradalom” (,, Rousseau et la Révolution”), „,Rousseau és a szinház” (,Rousseau et le spectacle”), „Rousseau zenei szótára és ennek európai fogadtatása” (, Le Dictionnaire de musique de Rousseau et sa réception européenne”), „Rousseau, természet és kultúra. Irodalom és filozófia.” (,, Rousseau, nature et culture. Littérature et philosophie"). Londonban a Londoni Egyetem (University College London - UCL) kiállítást szervezett „Rousseau 300: természet, az egyén és az állam" (Rousseau 300: Nature, Self and State) címmel. A kiállítást összehangolták egy nagyobb konferenciával, amely keretében Rousseau örökségének újraértékelését járták körül a szakemberek. Kulturális programként pedig A falusi jóst mutatták be. Európában még a koppenhágai Aarhus Egyetem (Aarhus University) pedagógiai tanszékének szervezését emeljük ki, amely „Rousseau-t keresve” (Looking for Rousseau) címmel szervezett szimpóziumot. Európa és Ázsia határán, Isztanbulban is szimpóziumot szerveztek május elején ",Rousseau és Törökország” (,,Rousseau et la Turquie”) címmel. Ez egy háromnyelvü rendezvény volt, aminek célközönsége az egyetemi polgárok voltak, a hallgatók, kutatók, egyéb egyetemi érdeklődők. A Rousseau által az oszmán-török birodalomról írt leírások bemutatásán kívül a rendezvény célja volt, hogy körüljárják a filozófiai, politikai és irodalmi hatást a modern és a korabeli Törökországban. Hasonlóan, Iasnaia Poliana-ban, Tolsztoj szülővárosában, Oroszországban is szerveztek egy nemzetközi szimpóziumot „Lev Tolsztoj és Jean-Jacques Rousseau” (,Léon Tolstoï et Jean-Jacques Rousseau”) címmel. A körüljárt témák: Lev Tolsztoj 'rousseauizmusa', Tolsztoj és Rousseau öröksége Oroszországban, Tolsztoj és Rousseau a természetről, Tolsztoj és Rousseau a színházról és a zenérôl, Tolsztoj és Rousseau barátai és ellenségei, Tolsztoj 'rousseauizmusának' orosz és külföldi kritikája, valamint Rousseau munkáinak oroszra fordításának története. Tovább távolodva Rousseau szülőhazájától Kínát kell megemlítenünk, ahol két helyen is megemlékeztek a filozófusról. Egyrészt Guangzhou-ban „A franciák Rousseau-ja és a kínaiak Rousseau-ja. Rousseau a francia emlékezetben és a kinai emlékezetben” (,Le Rousseau des Français et le Rousseau des Chinois. Rousseau dans la pensée française et la pensée chinoise"). 
A négynapos konferencia fókusza a politikai filozófia, a szociológia, a filozófia és a vallás volt, a szervezést a Sun Yatsen Egyetem végezte, a francia és svájci konzulátusok és a Francia szövetség (Alliance Française) együttmüködésében. A másik rendezvény Nankin-ban volt, a Nankin-i Egyetemen (Université de Nankin) „Rousseau, a ma filozófusa címmel”. Ez a nemzetközi szimpózium Rousseau születésének 300. évfordulóról való megemlékezésére szerveződött, több egyetem dolgozóinak együttmüködésében, így a Nanjing-i Egyetem (Université de Nanjing), a párizsi Sorbonne (Université de Paris IV-Sorbonne), a Nankin-i Egyetem (Université de Nankin), a Diderot Egyetem modern és kortárs kínai tanulmányok tanszéke (Université Paris Diderot-Paris 7, Centre d'études sur la Chine moderne et contemporaine) és a Pekingi Egyetem. További érdekesség, hogy mindeközben Indiában (Pune, Maharashtra) megrendezésre került az első indiai szeminárium „Rousseau újralátogatása” (Revisiting Rousseau") címmel. Az ülést a Pune-i Egyetem (University of Pune) szervezte a Francia szövetséggel és a svájci konzulátussal együttmüködve. Az amerikai kontinensen sem hagyták figyelmen kívül a tricentenáriumot. New Yorkban „Rousseau és a nagy gondolkodók” (,,Rousseau and the Great Tthinkers”) címmel rendeztek konferenciát, „,Hol van Jean-Jacques Rousseau helye a nyugati politikai tradicióban?" tematikával. A konferencia a születésnap 300. évfordulója mellett az ünnepelt két munkájának, a Társadalmi szerződés és az Émile megírásának a 250. évfordulóját is ünnepelték. A konferencián nemzetközileg elismert tudósok vettek részt az Egyesült Államokból és Európából, és vitatták meg Rousseau hosszan tartó nagyságát és örökségét más nagy gondolkodókkal összevetve, úgy mint Machiavelli, Montaigne, Moses Mendelssohn vagy akár Karl Marx. Rousseau közép- és dél-Amerikában is népszerüségre tett szert. Mexikóvárosban is nemzetközi szimpóziumot szerveztek „,Rousseau dél-Amerikában: a Bourbon reformoktól a függetlenségi forradalomig” (,,Rousseau en Amérique latine: du réformisme Bourbon aux révolutions d'indépendance") címmel. A rendezvényt november végén tartották, a Történeti Kutatóintézet (Instituto de Investigaciones Históricas) rendezésében. Peruban, Limában pedig ,Rousseau aktualitása a 21. században” (La actualidad de Russeau en el siglo XXI) címmel rendezett szemináriumot az Universidad Nacional Mayor de San Marcos.

Látható, hogy a 2012-es Rousseau-i év gazdagon szervezett rendezvényekkel volt tele szerte a világon. Rousseau hosszan tartó hatása érezhetően jelen van Ázsiától Európán át az Egyesült Államokig. François Jacob, a Rousseau program genfi szervezője találóan mondja egy interjúban, hogy amikor Rousseau megírta az Esszé a nyelvek eredetéröl címủ munkáját, leírta, hogy az embereket mennyire alakítja az a hely, ahova születtek, és annak a csoportnak a kultúrája, ami körülveszi öket miközben felnőnek. Ez a gondolat a mai globalizált szocializációs környezetben sem vesztette érvényét. Vajon mit írna, hogy vélekedne Rousseau a globalizációról? Vajon mit érezne akkor, amikor megtudná, hogy a világ mely sok pontján ünnepelték a születésének 300. évfordulóját? Jacob azt mondja, hogy nem véletlen, hogy 
Rousseau gondolkodásának legjobb fordítói Brazíliából jönnek, hiszen a nyelvekhez és a természethez való viszonyuk közel áll a felvilágosodás filozófusához. Hatása messzenyúló, hiszen az Egyesült Államok alkotmányának számos elemét Rousseau Társadalmi szerződés címú munkája inspirálta. Kimondható tehát, hogy a Svájcban született korabeli világpolgár több mint 300 évvel a halála után is rendkívüli hatással van a világ különböző pontjain élő emberekre. És ez talán össze is hozta őket egy évre azáltal, hogy mind ugyanarra figyeltek. Arra, hogy párbeszédet folytassanak arról, amit Rousseau képviselt, találkozzanak, legyenek együtt, gondolkodjanak együtt filozófiai, szociológiai, pedagógiai, vallási és politikai kérdésekről, és beszélgessenek irodalomról, színházról, zenéről.

\section{Irodalom}

Adamo, G. (2012): Geneva to blow out 300 candles to Rousseau - interjú François Jacobbal, a Rousseau program genfi szervezöjével. Swissinfo:

http://www.swissinfo.ch/eng/culture/Geneva_to_blow_out_300_candles_to_Rousseau. html?cid=31976674, swissinfo.ch Jan 20, 2012 - 14:26 Letöltés ideje: 2013. február 10.

Francia Nemzeti Könyvtár [Bibliothèque nationale de France $(\mathrm{BnF})]$ : http://www.bnf.fr/en/collections_and_services/educ_eng/s.education_books_journals.html Letöltés ideje: 2013. február 22 .

Genf város weboldala: - 2012 Rousseau pour tous (2012 Rousseau mindenkinek) rendezvénysorozatra készített online felület: http://www.ville-ge.ch/culture/rousseau/ Letöltés ideje: 2013. január 25.

Le Figaro: http://www.lefigaro.fr/culture/2012/06/28/03004-20120628ARTFIG00456-jeanjacques-rousseau-fete-ses-300-ans.php Letöltés ideje: 2013. február 10.

Le Temps: http://www.letemps.ch/dossiers/dossiers_2012/2012_rousseau

Rhône-Alpes régió weboldala: http://www.rhonealpes.fr/622-rousseau-2012.htm

Rousseau chemins ouverts: http://www.rousseau300.ch/ Letöltés ideje: 2013. február 22.

Rousseau Egyesület / Rousseau Association:

http://rousseauassociation.ish-lyon.cnrs.fr/conferences/otherConferences.htm Letöltés ideje: 2013. február 22. 